\title{
Fabrication of a New Series of Quaternary Alloys through Hybrid Phase Sintering
}

\author{
M.P. Trasadiya, A.M. Vora* \\ Department of Physics, School of Sciences, Gujarat University, Navrangpura, Ahmedabad-380009, \\ Gujarat, India
}

(Received 23 April 2020; revised manuscript received 15 October 2020; published online 25 October 2020)

\begin{abstract}
In modern technology, revolution plays a significant role in improving technology day by day, qualitatively and quantitatively. A new series of Al-Si-In-Sn quaternary alloys was fabricated through powder metallurgy (PM) route. In PM, density and porosity of the final product are strongly dependent on the sintering process. In order to increase the density, we have proposed hybrid phase sintering (HPS), which belongs to liquid phase sintering category. HPS is a combination of solid phase sintering and liquid phase sintering, in which two or more elements take part in solid phase sintering and two or more elements take part in liquid phase sintering to achieve full relative density. Therefore, HPS is only applicable for quaternary or high entropy alloys. We achieved $97.67 \%$ and $96.33 \%$ relative densities in a new series of $\mathrm{Al}_{100-x} \mathrm{Si}_{x} \mathrm{In}_{6} \mathrm{Sn}_{10}(x=12,16)$ quaternary alloys using HPS at $600{ }^{\circ} \mathrm{C}$ in tubular furnace with an argon atmosphere. We also observed that one parameter of PM affects all other parameters of PM. Therefore, we have tried to express the effect of the parameter in the form of a PM super hexagon.
\end{abstract}

Keywords: Hybrid phase sintering (HPS), Al-Si-In-Sn quaternary alloy, Powder metallurgy (PM) superhexagon, Density and porosity.

DOI: 10.21272/jnep.12(5).05019

PACS numbers: 81.05.Bx, 81.05.Zx, 81.20.Ev

\section{INTRODUCTION}

Aluminum offers a wide range of properties that can be engineered precisely to the demands of specific applications through the choice of alloy, temperature, and fabrication process [1]. Aluminum is one of the greatest elements to reduce weight of the material [1]. Aluminum and its alloys are extensively used in buildings and constructions, containers and packaging, marine, aviation, aerospace and electrical industries because of their lightweight, corrosion resistance in most environments, and good mechanical properties [2]. Properties of aluminum and its alloys can be enhanced by adding a modifier. Aluminum-silicon alloys have the potential for excellent castability, good weldability, good thermal conductivity, high strength at elevated temperatures and excellent corrosion resistance [2]. AlSn based alloys are widely used as sliding bearing materials in automobile and shipbuilding industries [3]. Excellent tribological properties can be achieved in $\mathrm{Al}$ Sn alloys when the soft Sn-rich phase is dispersed homogeneously into the $\mathrm{Al}$ matrix [4].

Recently, quaternary alloys and high-entropy alloys (HEAs) have taken considerable attention due to their extraordinary properties, such as high strength with reasonably good ductility, good hardness, lightweight, corrosion and wear resistance [5]. There are several processing and fabrication routes explored for optimization of processing conditions and properties [5].

In the present work, we have fabricated an aluminum based Al-Si-In-Sn lightweight quaternary alloy. These alloys can be produced by the melting-casting route preferably through vacuum induction melting or arcmelting processes, and powder metallurgy (PM) [5].

However, this alloy can be difficult to produce by melting route due to the large difference in melting points of each element. Therefore, PM technique is suitable for fabricating such types of alloys. The most significant steps of PM technique are mixing of powders, compaction, and sintering [6]. In PM, sintering plays an essential part during the operation [6]. The density and properties of the final product in PM are strongly dependent on the sintering. In short, we can say sintering is the heart of PM. Based on the results obtained, we have proposed another type of liquid phase sintering - hybrid phase sintering. Hybrid phase sintering was carried out under the argon protective atmosphere. Relation between each step of PM was represented in form of PM super hexagon.

\section{EXPERIMENTAL PROCEDURES}

\subsection{Metal Powders}

A fine powder of aluminum, tin, indium, and silicon elements with high purity greater than $99.9 \%$ was selected for fabricating a quaternary semiconductor alloy by PM route. Ultra-fine powder of aluminum and tin (44 microns) was received from "Bhoomi metals and alloys". Pure silicon lumps were received from crystal foundry fluxes. Pure indium was received from Swiss alloy. Firstly, pure silicon lumps were converted into fine powder with the help of agate mortar. As we know, metallic indium is a malleable metal, so we cannot easily get its powder. So, indium was cut into a very small size with the help of a doctor blade for $4 \mathrm{~h}$.

\subsection{Mixing and Blending}

The term blending is very useful for singlecomponent action, whereas the term mixing involves two or more metal powders [7]. An appropriate weight percentage of aluminum, silicon, tin and indium was measured by analytical weight balance carefully. A fine powder mixture was fabricated in the lab for the proper

\footnotetext{
*voraam@gmail.com
} 
homogeneous mixture of each powder sample [6]. The powder mixture rotated at $70 \mathrm{rpm}$ for $1 \mathrm{~h}$ each sample.

\subsection{Compaction}

Within an appropriate cylindrical die, mixed metal powder is compacted with high pressure [7]. Die compaction is the most widely used method which is known to be a standard technique for the consolidation of the powder into the desired shape [7]. Compaction was performed using a cylindrical die and punch (13.5 mm diameter). Mixed powders were poured into the cylindrical die cavity $(13.5 \mathrm{~mm}$ diameter $)$ and compacted by punch applying $700 \mathrm{MPa}$ pressure using the compressive testing machine (CTM) as shown in Fig. 1. The mixed powder was compacted in the desired shape that is called "green compact". Then, finally, green compact was taken out from the die cavity. The increase in pressure during the compaction process leads to an increase in densification.

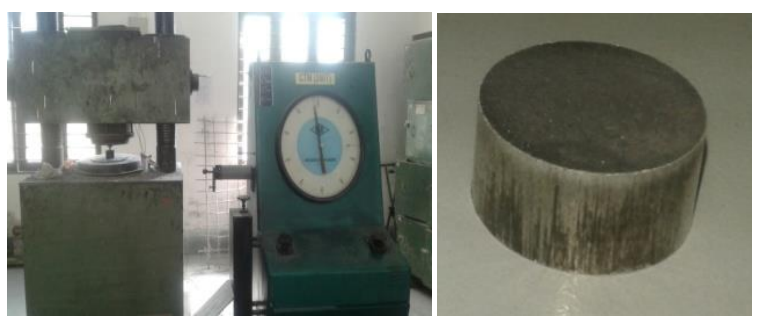

Fig. 1 - Compressive testing machine

Sintering is one of the most significant parameters of the process of PM. The sintering process is carried out under a protective atmosphere for preventing oxidation on the surface of the green compact. Sintering is one type of heat treatment processes that are carried out to improve density and some mechanical properties of the materials. In short, we can say sintering is the heart of PM. In this work, we have proposed another type of liquid phase sintering called hybrid phase sintering (HPS). HPS is a combination of solid phase sintering and liquid phases sintering. In this process, two or more elements take part in solid phase sintering, while two or more elements take part in liquid phase sintering to achieve full density of the material. HPS was carried out at $600{ }^{\circ} \mathrm{C}$ in tubular furnace with an argon atmosphere to prevent oxidation on the surface of the sample. The isothermal holding time for sintering was chosen to be $100 \mathrm{~min}$. Samples were placed in the center of a long quartz tub. At a temperature of $600^{\circ} \mathrm{C}$, indium and tin took part in liquid phase sintering due to the low melting point, while aluminum and silicon took part in solid phase sintering due to the high melting point. After completing the sintering process, the samples were taken out from the furnace.

\section{RESULTS AND DISCUSSION}

\subsection{Density and Porosity}

In this work, theoretical densities of both samples were calculated by using the rule of mixture [8]. An experimental density of the sintered quaternary alloy has been calculated by the formula of density. The theoretical densities of both samples of $2.939 \mathrm{~g} / \mathrm{cm}^{3}$ and
$2.919 \mathrm{~g} / \mathrm{cm}^{3}$ respectively were found as shown in Fig. 2 . However, sintered densities of samples $2.871 \mathrm{~g} / \mathrm{cm}^{3}$ and $2.812 \mathrm{~g} / \mathrm{cm}^{3}$ respectively were found as shown in Fig. 2 . Silicon is one of the lightweight elements. Therefore, we observed that the density of the sample decreased with increasing percentage of silicon. Porosity of the sample increased with decreasing density as shown in Fig. 3. We obtained a maximum relative density of the sample of $97.669 \%$ as shown in Fig. 3. However, we observed a relative density decrease with increasing silicon percentage. During the sintering process, when temperature rises, the particles are fused as a result of the formation of the necks between the particles, and liquid eliminates pores through capillary action which also contributes to an increase in densification [9]. Compaction pressure also affects the density and porosity of the material. In short, we can say that compaction pressure is directly proportional to the density of the material [10].

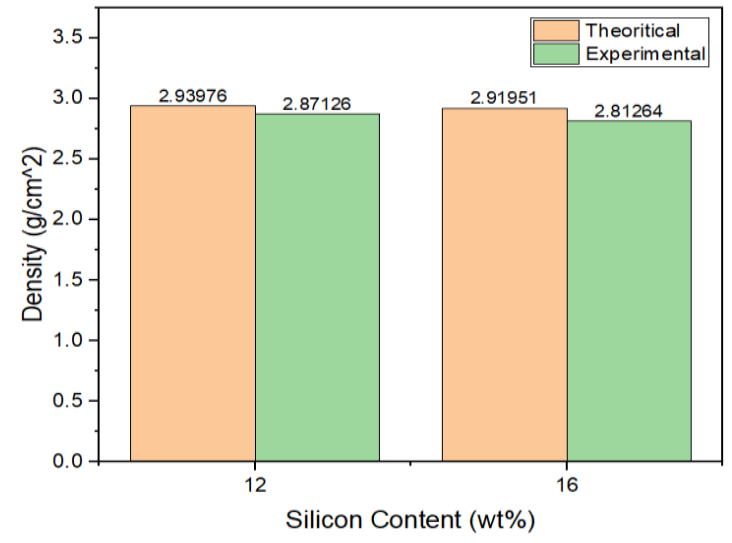

Fig. 2 - Theoretical and experimental densities

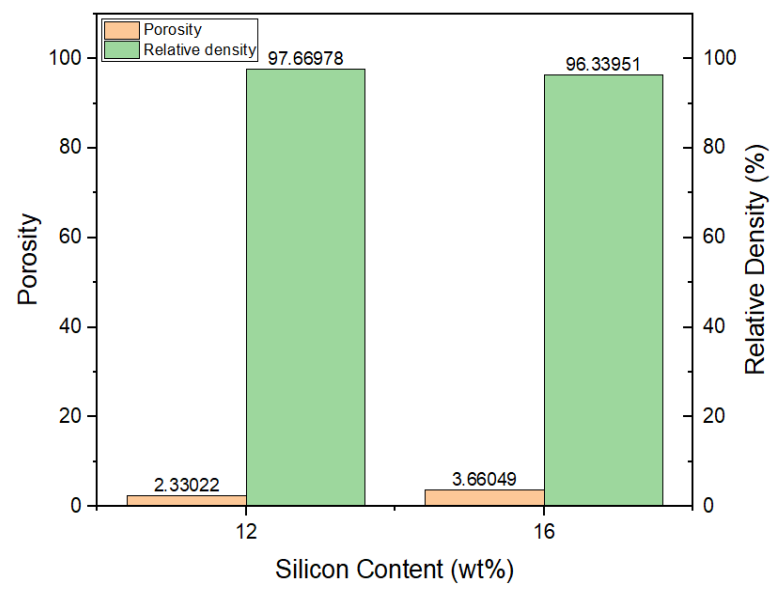

Fig. 3 - Porosity and relative density

\subsection{Hybrid Phase Sintering}

HPS is the formation of liquid during the sintering process, that leads to the elimination of pores and the formation of a bond between the particles. Therefore, we can achieve a high density of the sample. There are two types of HPS: the first type is normal HPS and the second one is stepwise HPS as shown in Fig. 4. Normal HPS, in which the sample is heated to the sintering temperature, is held at that temperature for a 
particular time, and then the sample is cooled with a desired rate. During heating, both low melting point elements become liquid at their melting points. At the sintering temperature, two liquid phases are present. Either the liquid phases may be soluble in each other or they may be insoluble in each other. However, this depends on the solid solubility limit of both liquids.

During solidification, the liquid phases are bound together with the solid phase. At the freezing point, the liquid starts to turn into a solid phase.

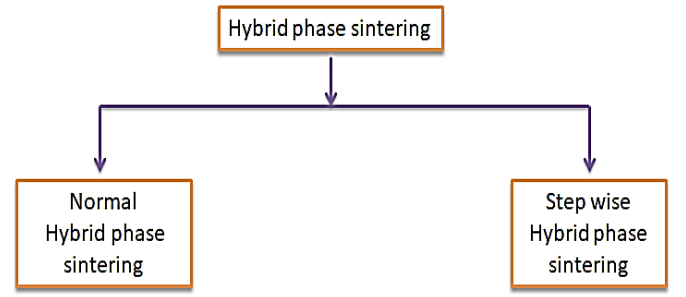

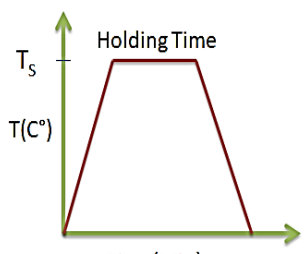

Time(Min)

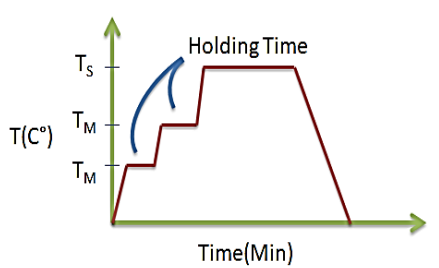

$\mathrm{T}_{\mathrm{S}}=$ (Sintering Temp.) $\quad \mathrm{T}_{\mathrm{M}}=$ Melting Point of Element
Fig. 4 - Types of hybrid phase sintering

Stepwise HPS is a process in which heating and holding steps are involved. Holding temperature is strongly dependent on the melting point of the metal. In short, holding temperature is equivalent to the melting point of the metal. Minimum two holding steps are involved before the sintering temperature. In this process, heating and holding steps are involved. Holding temperature is equal to the melting point of the element. Due to the involved steps, the liquid phase gets proper time to interact with a solid particle or eliminate pores in the sample. Therefore, we can achieve a full density with zero pore samples. During the cooling process, we can involve the same steps of heating because the cooling rate affects the properties of the sample.

The subsequent diffusion and shrinkage in the sintering of a liquid phase depend on the liquid-solid solubility relationship of the present phases [11]. Definitely, the percentage of the liquid phase must not exceed a fixed limit for any given system, since the compaction cannot retain the molten phase if that limit was exceeded [11]. The presence of a liquid phase usually decreases the sintering time and produces a denser and stronger product. However, specific situations sometimes result in an increase in volume or growth of the sample. This phenomenon is primarily associated with powders compressed at high pressures with a resulting entrapment of gases. During sintering, entrapped gases cause the compact to expand or grow [11].

In the present work, normal HPS was carried out on the green compact at $600{ }^{\circ} \mathrm{C}$ in a tubular furnace with an argon atmosphere. After the compaction, pores may exist in the sample as shown in Fig. 5. With increasing temperature, indium is converted to the liquid phase at
$156.6{ }^{\circ} \mathrm{C}$. Therefore, it spreads in the sample through capillary action. With a further increase in temperature tin is converted to the liquid phase at $231.3^{\circ} \mathrm{C}$.

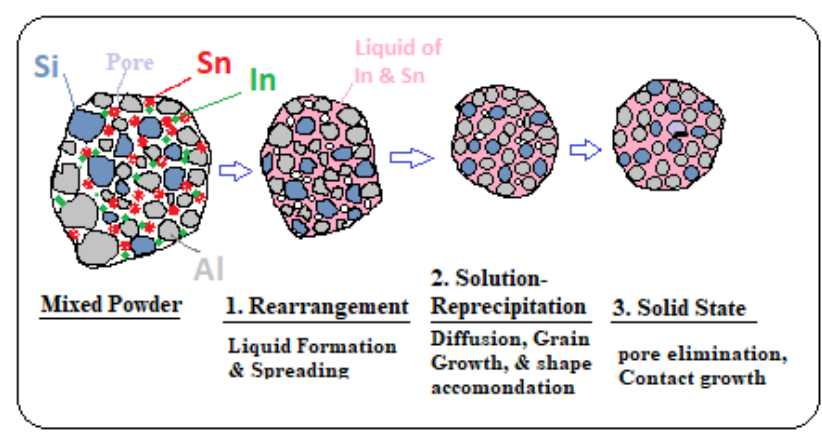

Fig. 5 - Classical steps of liquid phase sintering

At sintering temperature, the microstructure comprises a variety of grain sizes, grain shapes, and pores, each with different capillary conditions. There is a wide variety of capillary conditions [12]. A wetting liquid tries to move towards the lowest energy configuration, probably to smaller grains and pores [12]. That gives rise to rearrangement densification. Due to the rearrangement, pores are eliminated that leads to densification [12]. Finally, we achieved a maximum density of the sample of $97.66 \%$. However, we can achieve full density of the sample, but it depends on the fraction of liquid phase, sintering temperature and time. In this work, overall, all properties of the sample are modified due to the presence of two different liquid phases during the sintering process.

\subsection{Powder Metallurgy Super Hexagon}

PM is characterized by several parameters like particle size and shape, composition, compaction, sintering, density, porosity and properties. PM super hexagon (PMSH) demonstrates how one parameter relates to others (Fig. 6).

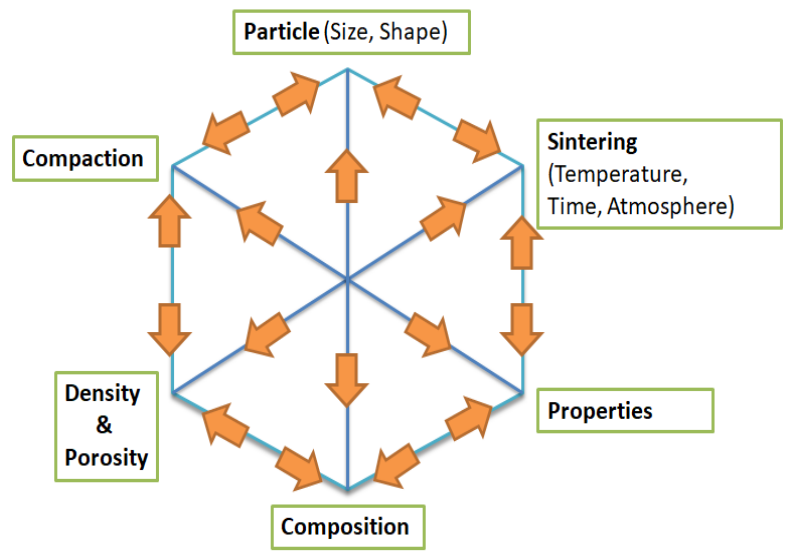

Fig. 6 - Powder metallurgy super hexagon (PMSH)

PMSH represents that one parameter relates to all other parameters. Particle size and shape affect the final product properties. If the particle size is large and particle shape is spherical, then voids may be present between the particles, hence the overall density of the material decreases and porosity increases. 
Vetayanugul et al. [13] have noted that after sintering the irregular powder yielded a material with higher density (less porosity) than the spherical powder. They have also observed that the particle size of the powder affects the amount and size of porosity as well as mechanical properties. Hlosta et al. [14] have written that the biggest irregular iron particles exhibit very low compressibility of about $2 \%$ at $15 \mathrm{kPa}$ of applied normal stress. Sanchez et al. [15] have reported that the green strength and transverse rupture strength (TRS) increase as particle size diminishes. De Mello et al. [16] have noted that the decreasing powder size always leads to high hardness.

Suresh et al. [17] have reported that the iron powders with an average particle size in the range of 2 to 150 microns show a linear relationship between green density and pressure. Daud et al. [18] have reported that the grains and bulk density increase with increasing sintering temperature and sintering times. However, opposite results were obtained for apparent porosity, hardness and compressive strength, while Dixit et al. [10] have reported that the compaction pressure highly influences the pore size as well as the number of pores. With increasing compaction pressure, the surface contact area of the powder particles increases which reduces the porosity. Sintering time and temperature also do affect the properties of the final product. Schubert et al. [19] have written that only pure nitrogen is an active sintering atmosphere for aluminum, because it promotes shrinkage and sintered mechanical properties [19].

$\mathrm{Xu}$ et al. [20] have stated that the density, weight loss, and tensile properties increase with the increase in the isothermal holding time for Fe-Mn-Si alloy. Porous material or membrane can be easily fabricated by PM. Compaction pressure plays a significant role during the fabrication of porous materials [3]. The relation between the compaction and sintering is based on the application. During the fabrication of porous materials, compaction and sintering play a significant role because the main aim of porous materials is based on the low density and high porosity.

\section{CONCLUSIONS}

A new series of Al-Si-In-Sn quaternary alloys was successfully fabricated by the PM technique with HPS for different silicon percentage. According to the results, the most important points are discussed below.

1) We have achieved densities of both samples as $2.87 \mathrm{~g} / \mathrm{cm}^{3}$ and $2.81 \mathrm{~g} / \mathrm{cm}^{3}$, respectively. Due to the low density, they can be used in lightweight applications. The results demonstrate that the density of samples decreases with increasing percentage of silicon.

2) We fabricated a new series of quaternary alloys with a relative density of $97.66 \%$ through HPS. Therefore, HPS can be used in the fabrication of ceramic-based metal matrix composite to achieve high density with less porosity. We can also achieve full density by changing sintering temperature and time.

3) Based on the results of density, HPS plays an effective role to enhance density of the sample.

4) PMSH gives an idea about the relationship between the parameters of PM.

\section{ACKNOWLEDGEMENTS}

Authors are thankful to the funding agencies DST, New Delhi, UGC, New Delhi for providing financial assistance through DST-FIST projects SR/FST/PSI001/2006 and SR/FST/PSI-198/2014 as well as DRSSAP program grants [No. F.530/10/DRS/2010(SAP-1) and No. F.530/17/DRS-II/2018(SAP-1)], respectively, to develop experimental facilities which were used to carry out this work.

\section{REFERENCES}

1. J.R. Davis, Handbook of Corrosion of Aluminum and Aluminum Alloys (ASM International: 1999).

2. M.M. Haque, J. Mater. Proces. Technol. 55, 193 (1995).

3. X. Li, L. Zhang, X. Yin, Mater. Sci. Eng. A549, 43 (2012).

4. N.A. Belov, T.K. Akopyan, I.S. Gershman, O.O. Stolyarova, A.O. Yakovleva, J. Alloys Compd. 695, 2730 (2017).

5. R.B Mane, B.B. Panigrahi, J. Mater. Res 33, 3321 (2018).

6. R. Purohit, R.S. Rana, C.S. Verma, IJERA 2, 420 (2012).

7. Y.K. Gautam, N. Somani, M. Kumar, S.K. Sharma, $1^{\text {st }}$ International Conference on Mechanical and Materials Science Engineering, AIP Conference Proceedings, 020017 (2018).

8. F.H. Latief, N.A. Alsaleh, N. Alrasheedi, S. Ataya, Oxid. Met. 92, 561 (2019).

9. E. Ghasali, R. Yazdani-rad, K. Asadian, T. Ebadzadeh, J. Alloys Compd. 690, 512 (2017).

10. M. Dixit, R.K. Srivastava, IOP Conf. Ser. Mater. Sci. Eng. 377, 012209 (2018).

11. D. Labrum, J. Am. Soc. Nav. Eng. 62, 63 (1950).

12. R.M. German, P. Suri, S.J. Park, J. Mater. Sci. 44, 1 (2009).

13. S.S. Anand, B. Mohan, Int. J. Mater. Eng. Innov. 3, 259 (2012).

14. J. Hlosta, D. Žurovec, L. Jezerská, J. Zegzulka, J. Nečas, Met. 2016-25th Anniv. Int. Conf. Metall. Mater. Conf. Proc. 1394 (2016).

15. F. Sánchez, A. Bolarin, J. Coreno, Powder Metall. 44, 351 (2001).

16. J.D.B. De Mello, R. Binder, A.N. Klein, I.M. Hutchings, Tribology-Mater. Surf. Interfaces 44, 53 (2001).

17. K.R. Suresh, M.S. Krupashankara, Int. J. Innov. Res. Sci. Eng. Technol. 4, 18629 (2015).

18. Z.C. Daud, S.B. Jamaludin, Adv. Mater. Res. 173, 106 (2011).

19. T. Pieczonka, T. Schubert, S. Baunack, B. Kieback, Euro Powder Metall. Congr. Exhib. 1, 331 (2005).

20. Z. Xu, M.A. Hodgson, K. Chang, G. Chen, X. Yuan, P. Cao, Metals Mdpi. 7, 1 (2017). 


\title{
Виготовлення нової серії чотирикомпонентних сплавів шляхом гібридного фазового спікання
}

\author{
M.P. Trasadiya, A.M. Vora \\ Department of Physics, School of Sciences, Gujarat University, Navrangpura, Ahmedabad-380009, \\ Gujarat, India \\ У сучасній технології революція відіграе значну роль у якісному та кількісному щоденному \\ вдосконаленні технологій. Нова серія чотирикомпонентних сплавів Al-Si-In-Sn була виготовлена \\ методом порошкової металургії (PM). В РМ густина та пористість кінцевого продукту сильно залежать \\ від процесу спікання. Для збільшення густини ми запропонували гібридне фазове спікання (HPS), \\ яке відноситься до категорії спікання рідкої фази. HPS - це комбінація спікання твердої та рідкої фаз, \\ в якому два або більше елементи беруть участь у спіканні твердої фази і два або більше елементи \\ беруть участь у спіканні рідкої фрази для досягнення повної відносної густини. Отже, HPS \\ застосовуеться лише для чотирикомпонентних сплавів або сплавів з високою ентропією. Ми досягли \\ $97,67 \%$ та 96,33\% відносної густини в новій серії чотирикомпонентних сплавів $\mathrm{Al}_{100-x} \mathrm{Si}_{x} \operatorname{In}_{6} \mathrm{Sn}_{10}$ \\ $(x=12,16)$ із застосуванням HPS при $600{ }^{\circ} \mathrm{C}$ у трубчастій печі з атмосферою аргону. Ми також \\ спостерігали, що один параметр РМ впливае на всі інші параметри РМ. Тому ми спробували виразити \\ вплив цього параметра у вигляді супер шестикутника PM.
}

Ключові слова: Гібридне фазове спікання (HPS), Чотирикомпонентний сплав Al-Si-In-Sn, Супер шестикутник порошкової металургії (PM), Густина та пористість. 